\title{
Faunistic survey of the zooplankton community in an oligotrophic sinkhole, Cenote Azul (Quintana Roo, Mexico), using different sampling methods, and documented with DNA barcodes
}

\author{
Lucia MONTES-ORTIZ, Manuel ELÍAS-GUTIÉRREZ* \\ El Colegio de la Frontera Sur, Avenida Centenario Km 5.5, Chetumal 77014, Quintana Roo, Mexico \\ *Corresponding author: melias@ecosur.mx
}

\begin{abstract}
This study is the first faunistic inventory of a zooplankton community from an open, karstic and oligotrophic aquatic sinkhole in the south of the Yucatan Peninsula (Mexico), we describe the richness of the zooplankton collected with the combination of plankton nets and light traps of our own design, using morphological and molecular characters to identify the species and demonstrate the effectiveness of only one set of primers to sequence all taxa. Recently, it has been demonstrated that different sampling methods can increase the number of zooplankton species from tropical and temperate systems dramatically. These more effective methods together with DNA barcoding can give a new and more realistic picture of the species dwelling in a freshwater system. In total, we sequenced 268 specimens, and the list of species known in this sinkhole increased from 13 to 77 taxa, with a projection of 87 in total, including cladocerans, copepods, ostracods, fish larvae, tadpoles, rotifers, chironomids, water mites, among others. From the 77 taxa identified by us, 72 BINS (Barcode Index Numbers, equivalent to putative species) were assigned by the BOLD Database (boldsystems.org), and 30 of them are new records for both, BOLD and GenBank (www.ncbi.nlm.nih.gov). There was an essential difference in the number of taxa collected with the plankton nets and the light traps. Only 23 taxa were registered in the nets, representing between 28 and $29 \%$ of the total richness, while 67 were present in the light traps representing $87 \%$ of the species found. From these, 46 taxa were exclusive to this sampling method. Light traps are an effective method for rapid evaluation of zooplankton. In the future, combining DNA barcoding and high-throughput sequencing methods with more efficient collecting will enable us to perform quick and precise biomonitoring of any aquatic ecosystem, enabling the detection of changes in zooplankton composition resulting from climate change and anthropogenic disturbances. Nevertheless, as a first step it is fundamental to establish a baseline of DNA barcodes for the species in these ecosystems.
\end{abstract}

Key words: Barcoding; biomonitoring; inventory; light-trap; bioindicators.

Received: December 2017. Accepted: May 2018.

\section{INTRODUCTION}

Zooplankton is a vital component in freshwater ecosystems, and is one of the first biological communities that will reflect the environmental changes or perturbation on their immediate habitat, such as species introduction (Attayde and Hansson, 2001; Jeppesen et al., 2001), eutrophication (Shiel et al., 1982), acidification (Keller et al., 1992; Walseng and Karlsen 2001), the presence of pesticides (DeLorenzo et al., 2002) or any other kind of pollution. In consequence, the changes in the composition of this community could be used as an indicator of the health status of a freshwater ecosystem (Mangas-Ramírez and Elías-Gutiérrez, 2004; Florian et al., 2016). However, the environmental evaluation will depend on a detailed knowledge of all species present in an aquatic system (Larigauderie et al., 2012), in other words in a welldocumented faunistic inventory.

Currently, a biomonitoring program based in the whole community is a complex task due to the difficulties to identify the species (Hajibabaei et al., 2012), and the complexity added by the variables of time and space in the sampling efforts. Particularly, identifying the species in the zooplankton community, using only the morphological characters requires a significant amount of time, as well as an extensive taxonomic knowledge for each group. Solving this problem requires an expert per taxonomic group. Alternatively, DNA barcoding (Hebert et al., 2003) has become a fast and consistent method for identification of species by non-experts (Teletchea, 2010). This methodology requires constructing reliable baselines (faunistic inventories) of the species using standardized genes as the COI (Elías-Gutiérrez et al., 2008). Currently BOLD (boldsystems.org; Ratnasingham and Hebert, 2007) is the most confident database for biodiversity because it links vouchers deposited in scientific collections with sequences and other metadata (Ratnasingham and Hebert, 2007).

In the other hand, the collecting methods in lakes have not changed in the last 100 years, despite their 
limitations due to the effects that are known as extrusion and evasion of the nets or traps (Harris et al., 2000; Devries and Stein, 1991). Recently, Elías-Gutiérrez et al. (2018) demonstrated the usefulness of light traps and DNA barcoding to establish a baseline for the zooplankton in several lakes from Mexico and Canada. Based on this and other experiences, we consider that a combination of potentially complementary sampling gears will provide a more comprehensive picture of the species dwelling in a particular region or habitat (Vásquez-Yeomans et al., 2011; Martínez-Luque et al., 2016; Marrero et al., 2008).

In this work, we will consider zooplankton following the reasoning indicated in the preface of the special volume edited by Dumont and Tundisi (1984), including not just the limnetic community, but also the littoral and groups that can be planktonts sporadically or in the larval stage only. Therefore, any individual capable of swimming into the light traps or trapped with net tows. The Cenote Azul is the biggest karstic sinkhole (cenote) located in the south of Quintana Roo state, in the Yucatan Peninsula (Mexico). It is in a good status of conservation and has particular properties of water geochemistry (Perry et al., 2002). It is a famous regional touristic attraction and is vulnerable to anthropogenic perturbations derived from population growth, like other freshwater ecosystems in the region (Elías-Gutiérrez et al., 2007; Elías-Gutiérrez et al., 2018).

This study aims to provide a reliable faunistic list, using different collection methods, of the zooplankton species from the Cenote Azul, with identifications based on morphology whenever possible, and the use of DNA barcoding tools as the BIN numbers.

\section{METHODS}

\section{Study area}

Cenote Azul (18.647 N and 88.412 W, Datum WGS84) is a cylindrical sinkhole, with a circular shape and a maximum deep of $65 \mathrm{~m}, 200 \mathrm{~m}$ diameter, with vertical walls from the surface to the bottom (CervantesMartínez et al., 2009), with no littoral development. It is located to the south of Quintana Roo state, Mexico (Fig.1). This sinkhole is a karstic, oligotrophic system, with maximum oxygen concentrations registered in dry (February-May) and rainy (June-October) seasons and the minimum in "nortes" (winter) season (NovemberJanuary), while the average annual temperature in the system is $29.2 \pm 0.9^{\circ} \mathrm{C}$ (Cervantes-Martínez et al., 2009), with no summer stratification.

\section{Sampling}

We conducted three sampling campaigns: first in September 2016, second in January 2017 and the third in
April 2017, corresponding to the rainy, "nortes" and dry seasons, respectively. The samples were taken during the new moon phase, to avoid diel vertical migration of zooplankton (Dodson, 1990). We used the combination of two sampling methods: vertical and horizontal tows using two plankton nets, with a mesh of $50 \mu \mathrm{m}$ and $200 \mu \mathrm{m}$, respectively.

The second sampling method was through light traps. We deployed three light traps, designed by us (Fig. 2) in each campaign at $5 \mathrm{~m}$ deep in the limnetic zone during 8 hours. We established three sampling points in the Cenote Azul: two near the shore zone (about $20 \mathrm{~m}$ from it) and one in the center of the water body. Close to the three sampling points where the light traps were deployed, we made a vertical tow up to $60 \mathrm{~m}$ deep with the nets of 50 $\mu \mathrm{m}$ and $200 \mu \mathrm{m}$ respectively, reaching the maximum deep in the bottom of the Cenote. Horizontal tows were carried out from one side to the other side of the system, in a distance of $150 \mathrm{~m}$, with each mesh size, at 9:00 pm, during the same night that light traps were working.

In total, after each sampling campaign, we obtained three light trap samples, six vertical tow samples (three from $50 \mu \mathrm{m}$ and three from $200 \mu \mathrm{m}$ ) and two horizontal tow samples (one from $50 \mu \mathrm{m}$ and one from $200 \mu \mathrm{m}$ ). All samples were sieved and washed with $96 \%$ ethanol to extract all water, and finally fixed with $96 \%$ ethanol. They were transported on ice from the field, and stored at $-18^{\circ} \mathrm{C}$ for seven days (Prosser et al., 2013; ElíasGutiérrez et al., 2018).

\section{Morphological analyses}

In the laboratory, the organisms were sorted into major taxa, using a stereo-microscope. The finest taxonomic identification was achieved using specialized keys only for cladocerans, copepods, water mites and monogonont rotifers (Koste, 1978; Suárez-Morales et al., 1996; Holynska et al., 2003; Elías-Gutiérrez et al., 2008b; Cook, 1980). The entire specimen preparations were deposited in the Reference Collection of Zooplankton at El Colegio de la Frontera Sur. Additionally, part of the material was prepared for morphological analyses with a scanning electron microscope (SEM) JEOL-JSM6010 (Fig. 3).

\section{DNA barcode analyses}

The specimens were placed into 96-well plates, and DNA extraction was carried out using a standard glass fiber method (Ivanova et al., 2006). DNA was extracted from whole individuals in the case of small taxa (e.g., rotifers and small cladocerans $<0.3 \mathrm{~mm}$ ). In this case, identical specimens from the same sample were deposited as vouchers. For water mites, voucher specimens were recovered after the lysis step from the glass fiber filter 


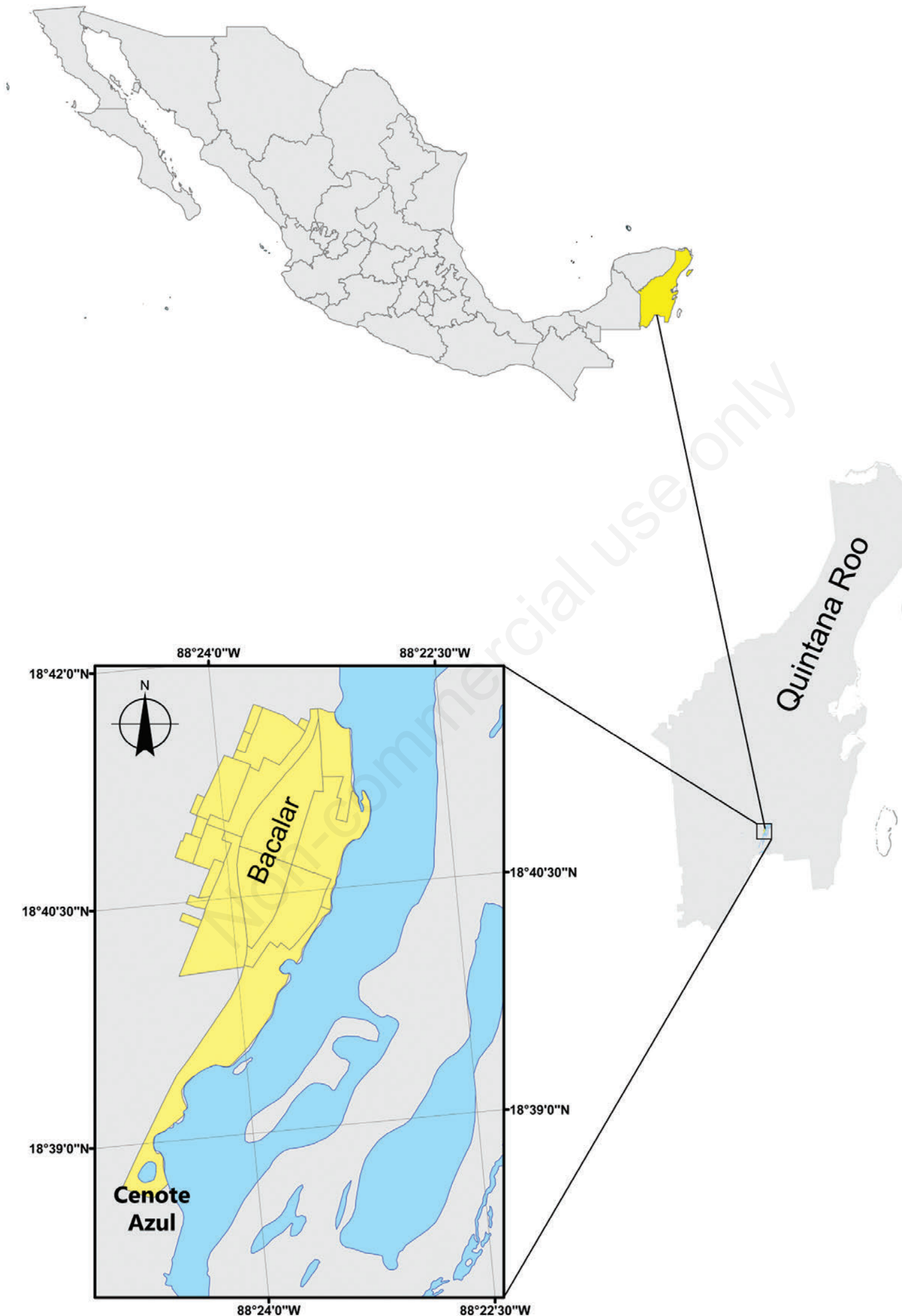

Fig. 1. Map of the location of the Cenote Azul in Quintana Roo, Mexico. 
plates or the 96-well original plates and preserved in 96\% ethanol with a drop of glycerol. For larger specimens, DNA was extracted from different tissue samples. For example, in case of copepods, the dorsal muscles of the cephalothorax or the eggs (in carrying egg females) were used, and all remaining appendages were mounted and stored. In other groups, like insects, only one fraction of a leg was dissected. Finally, for fish larvae, the eye of the right side was used. In all cases, the vouchers (specimens not lost during DNA extraction) were deposited in the Zooplankton Reference Collection at El Colegio de la Frontera Sur, Chetumal unit.

Following DNA extraction, the PCR mixtures contained a final volume of $12.5 \mu \mathrm{L}$, including $2 \mu \mathrm{L}$ of Hyclone ultra-pure water, $6.25 \mu \mathrm{L}$ of $10 \%$ trehalose (previously prepared: $5 \mathrm{~g}$ D-(+)-trehalose dehydrate, in $50 \mathrm{ml}$ of total volume of molecular grade ddH2O), 1.25 $\mu \mathrm{L}$ of 10X PCR buffer, $0.625 \mu \mathrm{L}$ of $\mathrm{MgCl} 2(50 \mathrm{mM})$,

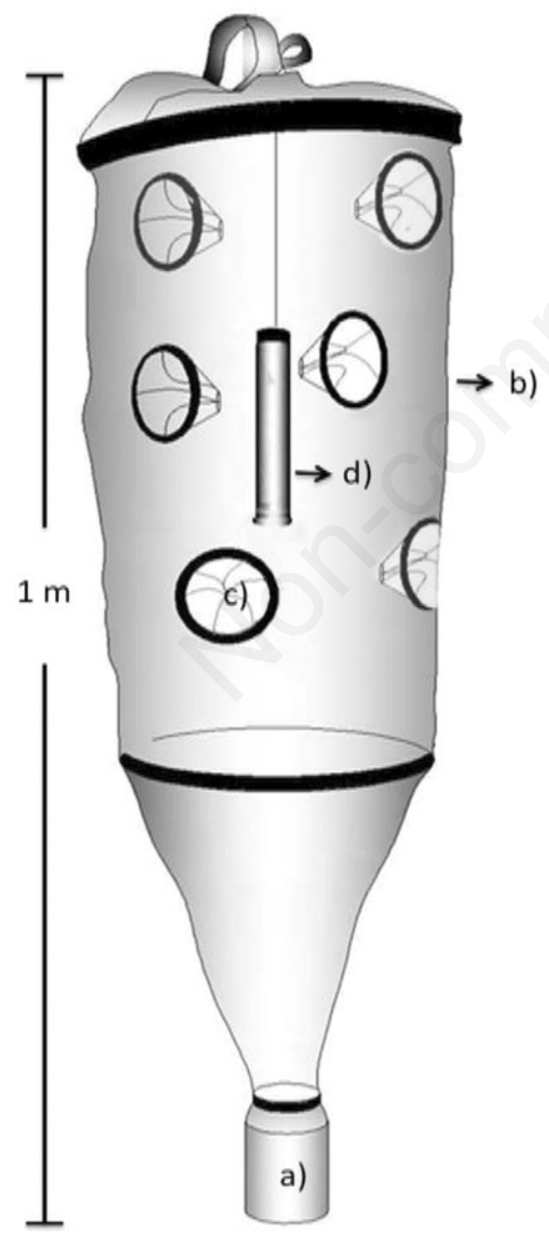

Fig 2. Light trap used in this study. a) Collector. b) Mesh (50 $\mu \mathrm{m})$. c) Entry funnel. d) Source of light (Scuba diving lamp Kraken( NR-650, 650 lumens).
$0.0625 \mu \mathrm{L}$ of dNTP $(10 \mathrm{mM}), 0.125 \mu \mathrm{L}$ of each primer $(10 \mu \mathrm{M}), 0.06 \mu \mathrm{L}$ of PlatinumTaq DNA polymerase and $2 \mu \mathrm{L}$ of DNA template. All specimens were amplified with the Zooplankton primers (ZplankF1_t1 and ZplankR1_t1, see Prosser et al., 2013 for details). The reactions were cycled at $94^{\circ} \mathrm{C}$ for $1 \mathrm{~min}$, followed by five cycles of $94^{\circ} \mathrm{C}$ for $40 \mathrm{~s}, 45^{\circ} \mathrm{C}$ for $40 \mathrm{sec}$ and $72^{\circ} \mathrm{C}$ for $1 \mathrm{~min}$, followed by 35 cycles of $94^{\circ} \mathrm{C}$ for $40 \mathrm{~s}, 51^{\circ} \mathrm{C}$ for $40 \mathrm{~s}$ and $72^{\circ} \mathrm{C}$ for 1 min, with a final extension of $72^{\circ} \mathrm{C}$ for $5 \mathrm{~min}$. PCR products were visualized on a $2 \%$ agarose gels (E-Gel 96 Invitrogen), and positive PCR products were selected for sequencing.

PCR products were sequenced using a modified (Hajibabaei et al., 2005) BigDye(C) Terminator v.3.1 Cycle Sequencing Kit (Applied Biosystems, Inc.), and sequenced bidirectionally on an ABI 3730XL automated sequencer using M13F and M13R primers at the Biology Institute at the National Autonomous University of Mexico. Sequences were edited using CodonCode v. 3.0.1 (CodonCode Corporation, Dedham, MA, USA) and uploaded to Barcode of Life Database (BOLD, boldsystems.org) and are available in the dataset Zooplankton Cenote Azul (DSCAZUL01). Additionally, sequences were uploaded to GenBank (www.ncbi.nlm.nih.gov).

All data were analyzed with the tools on BOLD, and all sequences were examined for the presence of stop codons and indels as a checkup against mitochondrial DNA-like sequences in the nucleus (NUMTS) (Ratnasingham and Hebert, 2007).

A Neighbor-Joining (NJ) tree was calculated using the Kimura two-parameter (K2P) distance model (Kimura, 1980) for all the groups (Rotifera, Mollusca, Arachnida, Crustacea, Insecta, Actinopterygii, Chordata) through the analytical tools provided by BOLD. We selected this method because it allows the rapid analysis of large datasets and since it has shown to perform well for species delimitation (Mutanen et al., 2016). The simplified tree was prepared using Mega 7.0 (Kumar et al., 2016).

All sequences which met minimum quality standards ( $>500 \mathrm{bp},<1 \%$ ambiguous bases, free of stop codons and contamination) were assigned a Barcode Index Number (BIN) on BOLD (Ratnasingham and Hebert, 2013). These BINS are automated assignments from BOLD and represent putative species (Elías-Gutiérrez et al., 2018).

Accumulation curves were calculated in BOLD and extrapolated to a maximum of 1000 individuals in EstimateS (Colwell, 2013), and total BIN richness for each system was estimated using the classic Chaol estimator in EstimateS.

Finally, we calculated the total richness for each sampling gear (light traps, horizontal trawls, and vertical trawls) assessing the representativeness of them with respect the whole richness estimated for the sampling gear used. 


\section{RESULTS}

A total of 268 sequences were obtained. We found 77 taxa (this means a taxon identified after morphology or the BIN, the latter considered as a putative species) comprising cladocerans, copepods, rotifers, arachnids, fishes, ostracods, chironomids, one amphibian and several other invertebrates. From these 77 taxa, 72 BINs were assigned by BOLD, 30 of them are new for the database (Tab. 1, Fig. 4). The difference between the taxa and the BINs is the result of the organisms in which DNA extraction was not successful, or the sequencing failed or did not accomplish all requirements to get a BIN (Ratnasingham and Hebert, 2013). Nevertheless, it was possible to get an identification exclusively with the morphological characters.

Within the taxa, the richest group was the arachnids, represented mainly by water mites, followed by the chironomids and cladocerans. In contrast, the rotifers, copepods, and ostracods had a lower richness. Some organisms sporadically appeared in the samples, for example, Mytilopsis (Bivalvia), Cirolanidae (Isopoda), Liposcelidae (Insecta), Psocodea (Insecta), Palaemonidae (Decapoda), and Ephemeroptera (Insecta), among others. In the group of arachnids, we identified 26 taxa from which 15 are water mites; four belongs to the Araneae order, seven to the subclass Acari: three mesostigmatids and four sarcoptiforms. The system assigned 25 BINs corresponding with all of them, except in the case of water mite Koenikea because the DNA extraction was not successful with it.

From the water mites group, only Arrenurus maya Ramírez-Sánchez and Rivas, 2013, represented by BIN ACX8463 and Arrenurus valencius Marshall, 1903 (BIN ADI3752) could be identified to species level, and six to genus. These are Hygrobates (BIN ACX7887), Koenikea
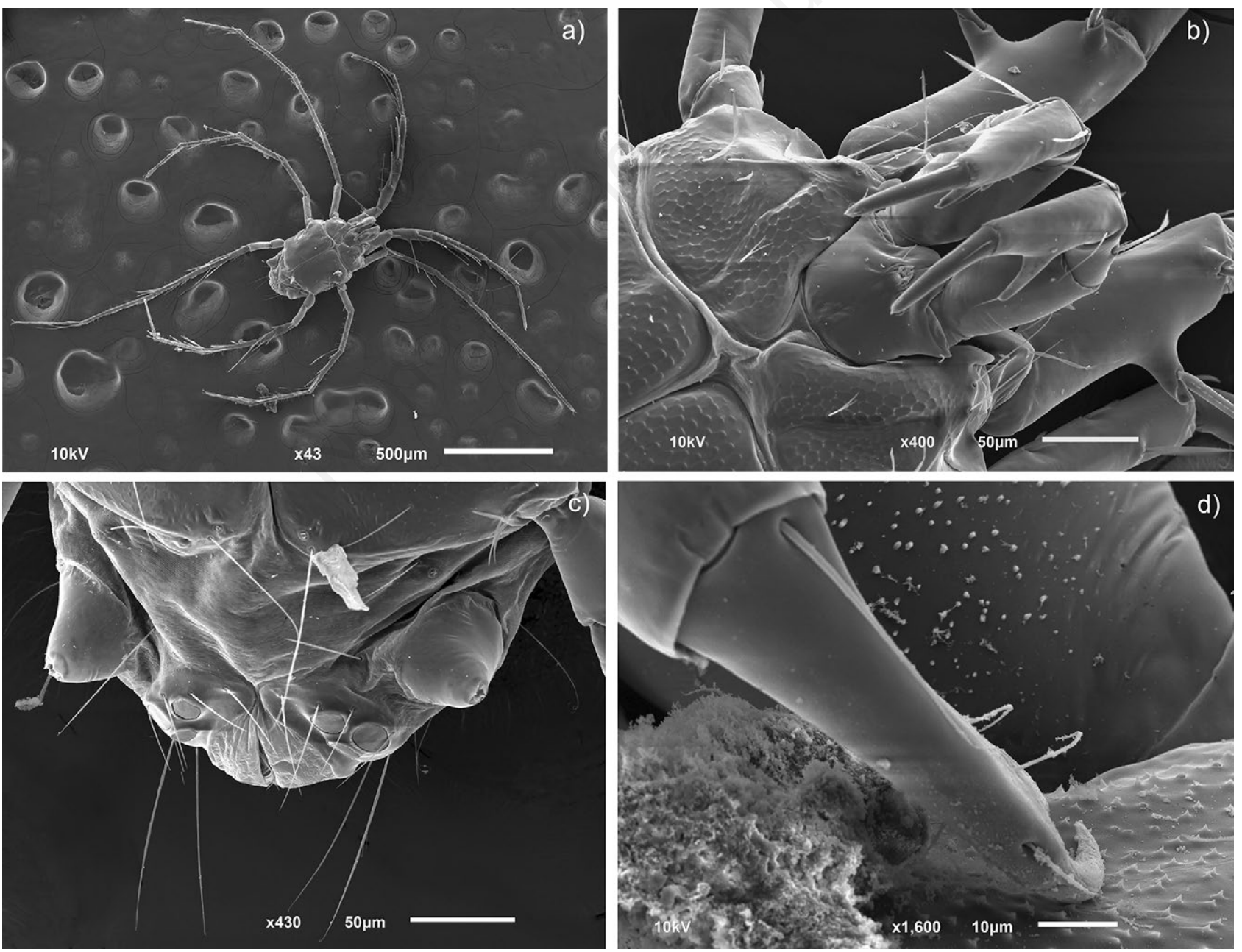

Fig. 3. Unionicola sp. BIN ACX9009. a) Ventral view. b) Palp and chelicera. c) Male, genital field. d) Palp detail. 
Tab. 1. Zooplankton and other groups collected in the Cenote Azul with different sampling methods.

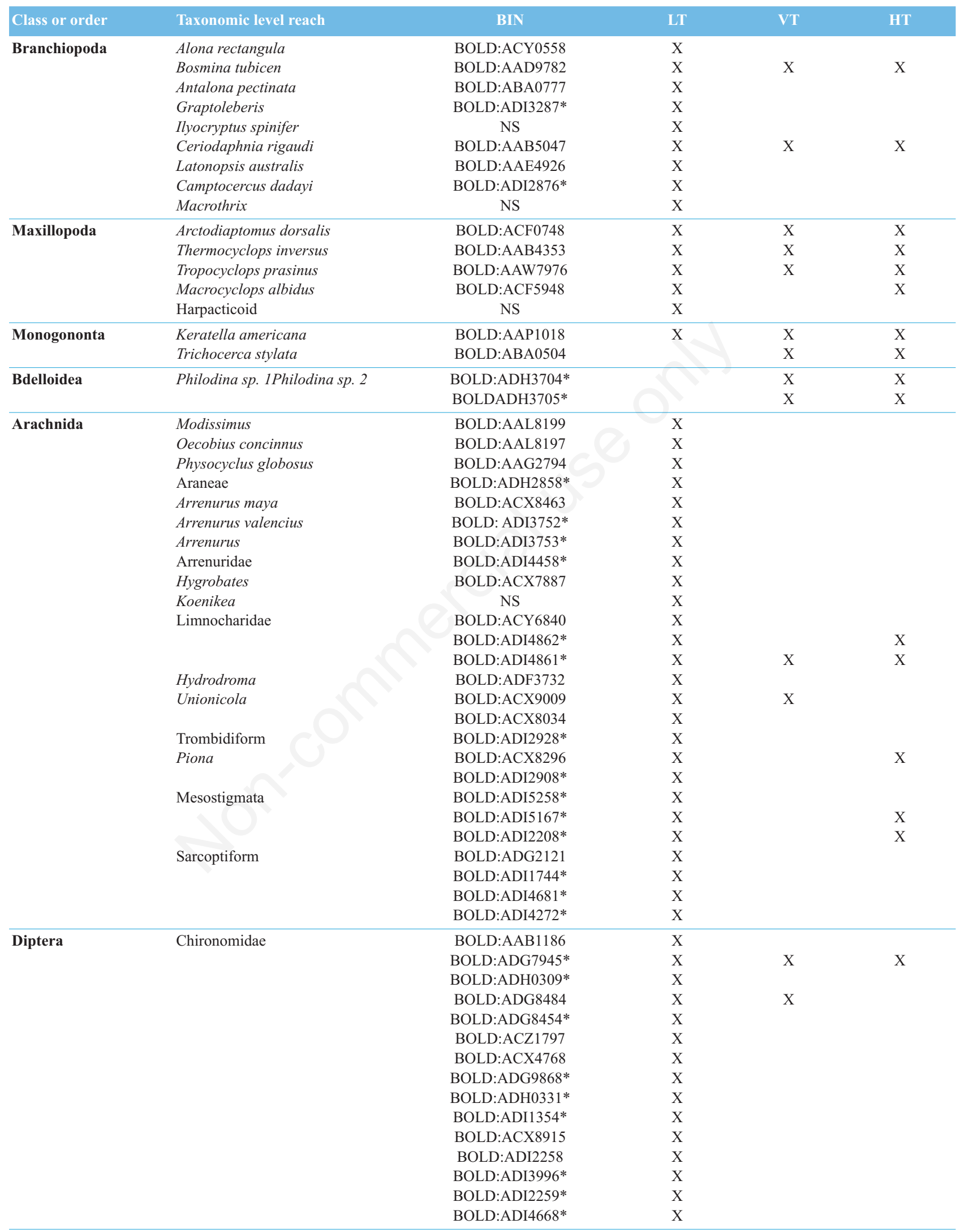


(the only one without sequence), Hydrodroma (BIN ADF3732), two Unionicola (BINS ACX9009 and ACX8034) (Fig. 3), and Piona (BINS ACX8296, ADI2908). The remaining ones were not identified yet, but have a BIN number assignment, meaning they are putative species. The second richest group, the chironomids were difficult to identify to genus; 15 BINS represented them (Tab. 1, Fig. 5).

From the three groups that traditionally are considered being part of freshwater zooplankton, cladocerans, copepods, and rotifers, we identified nine species of cladocerans represented by 29 specimens, from which seven received BIN assignments. Bosmina tubicen Brehm, 1953 (BIN AAD9782) and Ceriodaphnia cf. rigaudi (BIN AAB5047) were the most abundant cladocerans in the samples. In the case of copepods, from 45 specimens, 28 belong to Cyclopoida represented by Thermocyclops inversus (Kiefer, 1936) (BIN AAB4353), Tropocyclops prasinus (Fisher, 1860) (BIN AAW7976) and Macrocyclops albidus (Jurine, 1820) (BIN ACF5948) (Tab. 1). The Calanoida were represented by 17 specimens, all of them corresponding to Arctodiaptomus cf. dorsalis (BIN ACF0748). The rotifers were represented by Keratella americana Carlin, 1943 (BIN AAP1018), Trichocerca stylata (Gosse, 1851) (BIN ABA0504), and Philodina, this latter represented by two BINS (ADH3705, and ADH3704) (Tab. 1).

Ostracods found were Cyprinotus (BIN AAV0683) and three Cypria (ACY1494, ADH7095, and ADH7096).

We sequenced in total 21 fish larvae and they were clustered in four BINS corresponding to Dorosoma petenense (Günther, 1867) (BIN AAC3463), Atherinella alvarezi (Díaz-Pardo, 1972) (BIN AAI4788), Lophogobius cyprinoides (Pallas, 1770) (BIN AAB6671) and Ctenogobius fasciatus Gill, 1858 (BIN AAE7730) (Tab. 1, Fig. 4).

A particular case of a rare insect specimen was one larva of Gynaikothrips ficorum (Marchall, 1908) (BIN AAM8067) that was not possible to identify with morphology, but the identification tool on BOLD allowed to make a match with other specimens of this species in the database.

Finally, the tadpoles of Rhinella horribilis (Wiegmann, 1833) (BIN AAB1186) were the second vertebrate that appeared in the light traps. They were identified with the tools from BOLD.

All identifications and morphotypes found were correlated with the BIN assignment by BOLD.

According to the Chao 1 richness estimator, the number of expected species in the community is $88(95 \%$ confidence, intervals 63.96-163.92). Thus the observed richness corresponds to $87.5 \%$ of the total estimated richness for the community. The extrapolated BIN accumulation showed a smooth curvature around 87 BINs (Fig. 5) but did not reach the asymptotic value.

The light trap captured 67 taxa that represent $87 \%$ of the total richness, while the plankton net with vertical tows captured 23 taxa representing $29 \%$ of the richness, and plankton net with horizontal tows caught 22 taxa corresponding to $28 \%$ of the total (Fig. 6). From all registered taxa, 11 were common to the three sampling gears, whereas 46 taxa were exclusive to the light trap. Meanwhile, five were only in the vertical tows and one in the horizontal tows (Tab. 1; Fig. 6).

Table 1. Continued from previous page.

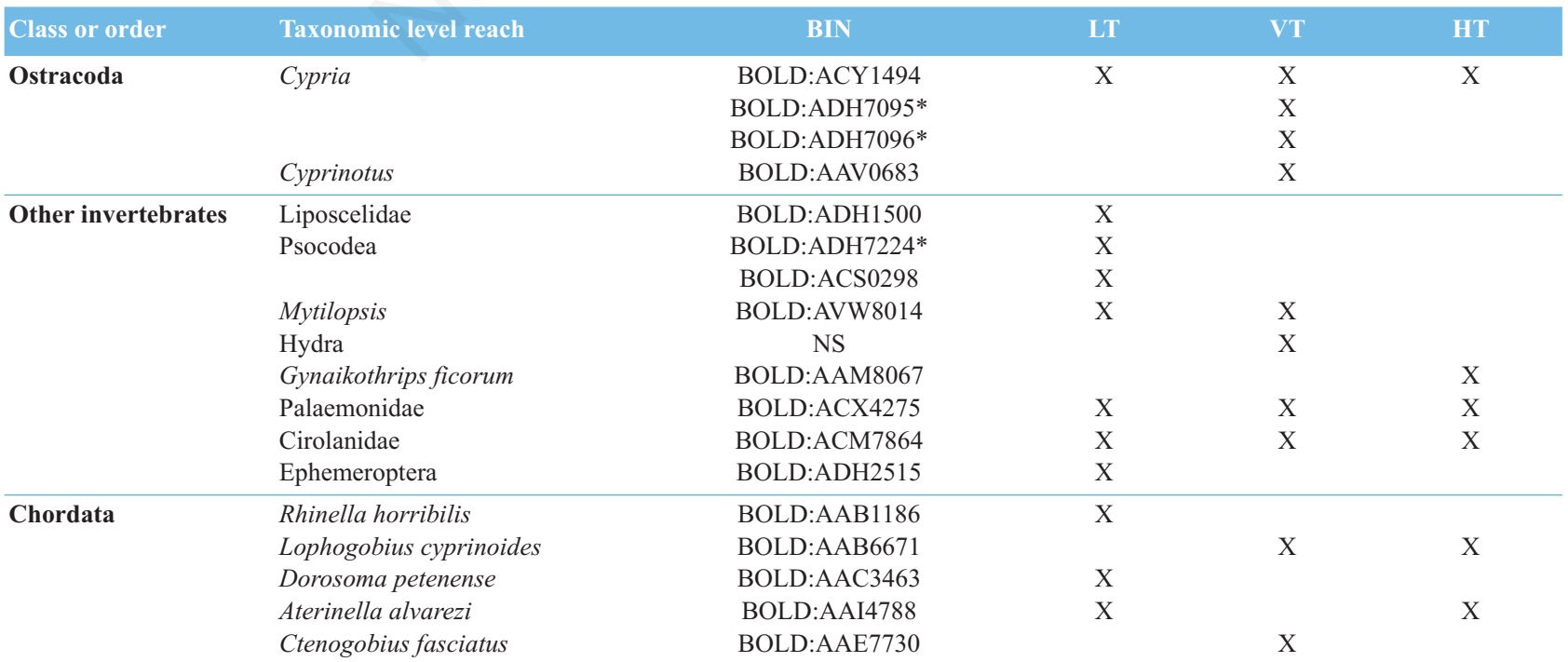

*New BINS in the BOLD system.: BIN, barcode index number; NS, no sequence obtained; LT, light-trap; VT, vertical trawls; HT, horizontal trawls. 


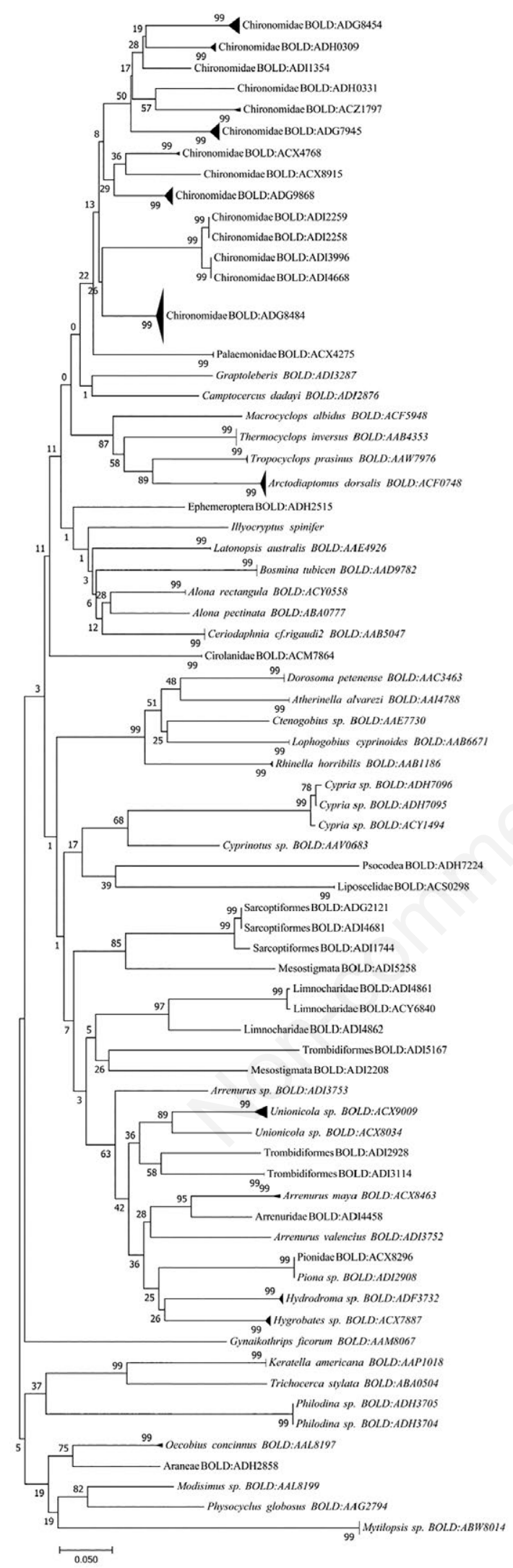

Fig. 4. Taxon ID tree for all groups present in the Cenote Azul. After the taxonomic name, it is the assigned BIN in BOLD.

\section{DISCUSSION}

Previously in the Cenote Azul, only 13 species of zooplankton were known, comprising rotifers, cladocerans, water mites, and copepods (Suárez-Morales et al., 1996; Otero-Colina, 1987; Kotov et al., 2004; García-Morales and Elías-Gutiérrez, 2004; Smirnov and Elías-Gutiérrez, 2011). With our study we increased the number of known taxa to 77 , particularly in groups which are rarely considered part of the zooplankton, but have clear planktonic adaptations (Modlin and Gannon, 1973; Davies, 1976; Janz et al., 2016; Deevey et al., 1980) such as water mites (Acari: Hydrachnidiae) and chironomids (Davies, 1976), both highly diverse and good indicators of water quality (Goldschmidt, 2016; Lindegaard, 1995) (Tab. 1). A particular case is the planktonic larvae of Mytilopsis, a mollusk also found in Lake Bacalar (Marelli and Berrend, 1978; Elías-Gutiérrez et al., 2018), located about $200 \mathrm{~m}$ from Cenote Azul. The nearest possible species is Mytilopsis sallei (Recluz, 1849), described from Lake Izabal, Guatemala, but it should be analyzed in more detail to confirm the identification (Elías-Gutiérrez et al., 2018).

Our work is the second in Cenote Azul that include the study of water mites. Previously, Otero-Colina (1987) recorded Unionicola mexicana Cook, 1980, Unionicola furculopsis Cook, 1980, Mideopsis nobilis Cook, 1980 and Neumania diversipalpa Cook, 1980. Additionally, DNA barcoding allowed identifying the mites from a nymphal stage as Arrenurus maya BIN ACX8463, a difficult task because the known characters are found only in the adults. As an example, we present the case of Unionicola sp. (Fig. 3 a-d), BIN ACX9009. In the key-book (Cook, 1980), it results in the diagnosis of genus Unionicola. Additionally, the obtained sequences match with the genera in the BOLD-Database that contains 618 sequences with 598 barcodes grouped in 29 species. In our case the BIN assignment ACX9009 belongs to 50 specimens in the database (www.boldsystems.org), located only in Lake Bacalar and Cenote Azul, this means a common species here. Both, morphological analysis and molecular data provide coincident delimitation with the genus, but the molecular data have $14.51 \%$ of distance to the closest species in the system. We need to analyze it in more detail to establish if it is new or it is an already known species, in the latter case with no sequence data yet.

In case of chironomids, we could identify only one genus, Coelotanypus, due to the poor taxonomic knowledge for this group in the region studied (Vinogradova and Riss, 2007). Most chironomid studies have been hampered by the notorious difficulties for the identification (Nyman et al., 2005). Nevertheless, the DNA barcoding approach seems to be a promising technique to help to face this problem (Pfenninger et al., 2007). On the other hand, it was interesting to see that 
some chironomid specimens emerged as adults inside of the light trap, allowing to match the pupae with the adult stage in four putative species (BINS: ADG8484, ADH0309, ADG8454, and ADG7945).

About cladocera, previously it was reported Macrothrix elegans Sars, 1901 (Kotov et al., 2004), Ceriodaphnia cornuta Sars, 1885 (Elías-Gutiérrez et al., 2001) and some Chydoridae (Smirnov and ElíasGutiérrez, 2011), all of them found after our study. Bosmina tubicen was the most abundant cladoceran in the system in contrast with Alona cf. rectangula, Antalona pectinata (Elías-Gutiérrez and Suárez Morales, 1999), Graptoleberis sp., Ilyocryptus spinifer Herrick, 1882, and Camptocercus dadayi Stingelin, 1913, which rarely appeared in the samples. Graptoleberis is a new record for this region. It is notable the presence of Latonopsis australis Sars, 1888 which was previously reported as limited to temporary pools and not found in permanent sinkholes or cenotes (Smirnov and Elías-Gutiérrez, 2011). Furthermore, in the Cenote Azul cladocerans were more common than the ostracods, an opposite case as previously reported by Smirnov and Elías-Gutiérrez (2011) for this region.

In the case of copepods, a form similar to
Arctodiaptomus dorsalis (Marsh, 1907) was the only calanoid found in the system. Suárez-Morales et al. (1996) identified it as A. dorsalis, being the same species as in Lake Bacalar according to him. However, we found that the BIN is different from the Bacalar specimens (Elías-Gutiérrez et al., 2018), indicating the possibility of cryptic species, a phenomenon already mentioned for this species (Elías-Gutiérrez et al., 2008a). Among cyclopoids, Cervantes-Martínez and Gutiérrez-Aguirre (2015) found that $T$. inversus is frequent and widely distributed in the south of Mexico in oligotrophic lakes. T. prasinus is more restricted, and it has been found in oligotrophic or mesoeutrophic conditions in Quintana Roo too.

From the rare specimens, the Cirolanidae and the Ephemeroptera are recorded for the first time in the south of Yucatan Peninsula (Rocha-Ramírez et al., 2009; Randolph and McCafferty, 2000).

The following invertebrates found are almost certainly accidental, due to their terrestrial habits. These are the Psocodea, Liposcelidae and G. ficorum. However, the last one was a larva. This species is a plague in ornamental plants and crops (Loera-Barocio et al., 2001). Also, it has been reported damage in the skin of persons who interacted with it (Piu et al., 1992). This species was

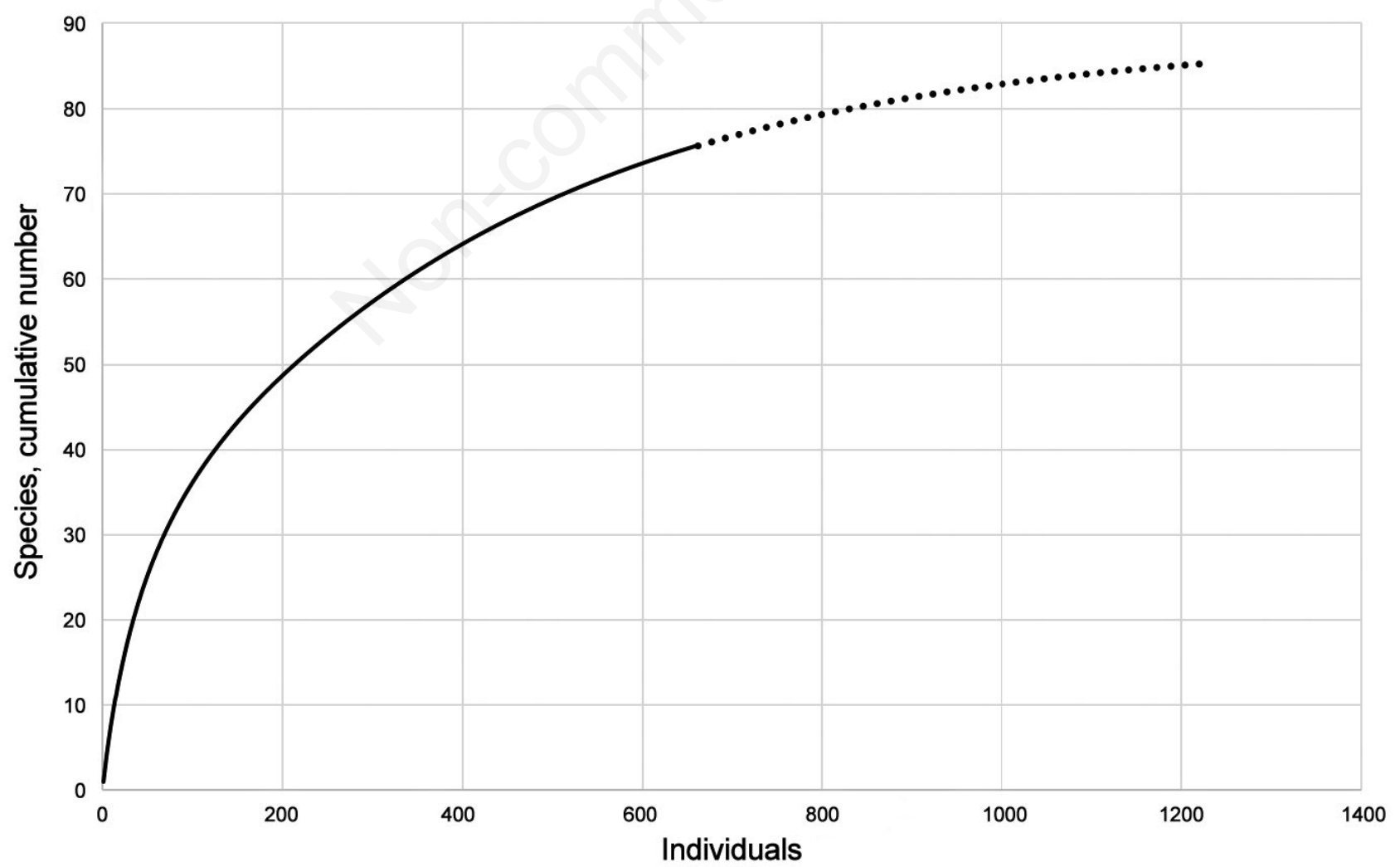

Fig. 5. Accumulation curve for BINS in the Cenote Azul. The dotted line indicates the extrapolation. 
found for the first time in the region. It seems to be an accidental catch by the plankton tows (Tab. 1).

As part of the meroplankton, we found Rhinella horribilis tadpoles, a common species in this region (González-Sánchez et al., 2017), and 21 fish larvae. From these, D. petenense and L. cyprinoides have been considered as freshwater fishes with tolerance to salinity. In contrast, $A$. alvarezi is endemic to Mexico and only found in freshwater (Miller et al., 2009). The presence of C. fasciatus has to be taken with caution because it is represented by a single specimen caught by a tow. Although our sequence has high quality, it will be necessary to obtain more specimens from this locality. Our sequence is the same as previous records from Lake Bacalar (Elías-Gutiérrez et al., 2018) and Panama (BIN AAE7730).

The accumulation curve indicates the need to continue the sampling effort to reach a complete baseline (Fig. 5). However, the total taxa recorded were 77 , whereas the Chaol measure indicates an estimated richness of 88 . If we consider the accidental caught and the specimens without sequence, the sampling gears almost reach the plateau from this curve in only three-nights, demonstrating the success of the collection methods, mostly the light traps. Although the performance of all sampling methods is different, since one represents an active collection method (zooplankton nets) while the other is a passive method, they were complementary. However, the light trap captured $87 \%$ of the total taxa found. Moreover, 46 of them, mainly chironomids, water mites, and cladocera were caught exclusively by the light trap (Fig. 6).

These results indicate that conventional zooplankton sampling methods are inadequate to capture a representative sample and many species remain unnoticed. Davies (1976) found that light traps caught planktonic organisms that usually avoid the nets as water mites, some immature stages of insects, several crustaceans, gastropods, fishes, and tadpoles (Barr, 1979; Hungerford et al., 1955). The use of light traps in conjunction with conventional methods might give a more comprehensive picture of zooplankton populations than traditional methods alone (Davies, 1976), allowing another kind of studies and the biomonitoring of any freshwater system.

The Cenote Azul has unusual water geochemistry and hydrogeological properties according to Perry et al. (2002), who considered this system an extreme environment, different to the nearby Lake Bacalar, found $200 \mathrm{~m}$ to the East. This effect is reflected in the biota. From the 72 BINS found in Cenote Azul, only 21 are share with Lake Bacalar, and B. tubicen is absent in the lake (Elías-Gutiérrez et al., 2018). Besides, there is a total absence of diatoms in the Cenote Azul; reinforcing the idea that zooplankton and other microinvertebrates assemblages are very likely to be specific in different aquatic ecosystems and they can be used as integral bioindicators.

\section{CONCLUSIONS}

This work is the first study using multiple sampling methods and DNA barcodes to create the possible most complete baseline for a freshwater oligotrophic karstic system. Although it was not likely to identify all species with morphology, each BIN is represented by specimens deposited in a Reference Collection. With the time they will be determined.

In case of morphological identifications, all of them were coincident with a representative BIN, indicating excellent discrimination after DNA barcodes.

We do not consider that light traps will replace the conventional methods to collect zooplankton. Instead, all these methods are complementary and will give a more

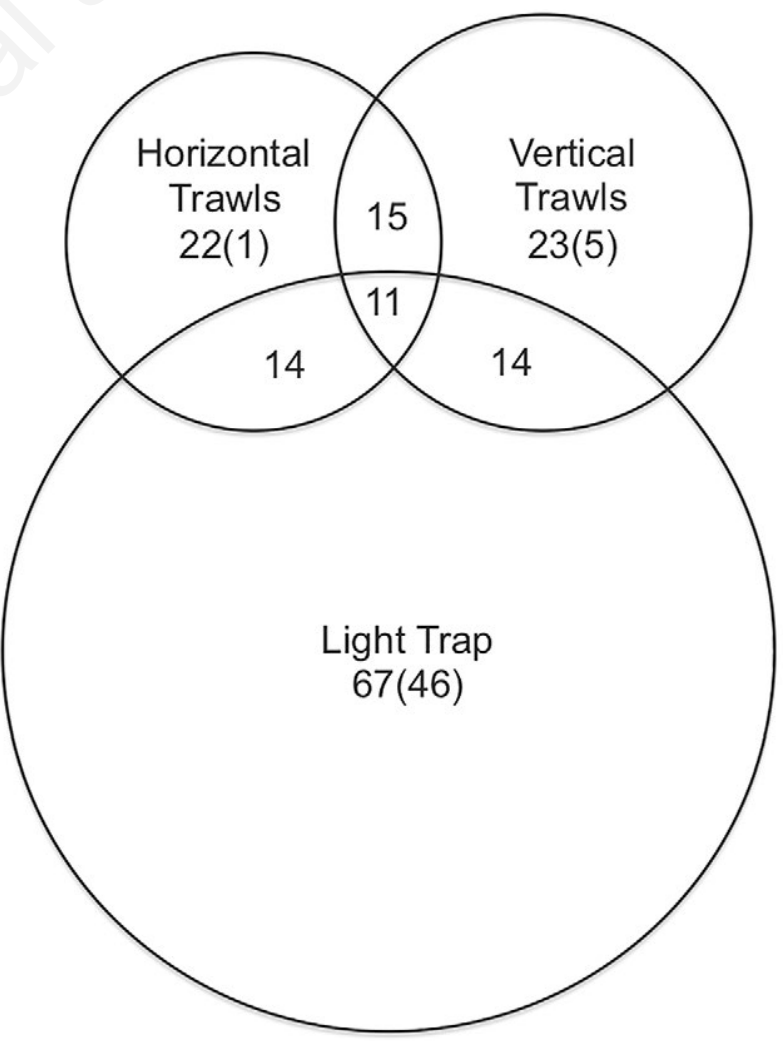

Fig. 6. Comparative species richness of zooplankton collected in the Cenote Azul, Quintana Roo, using different zooplankton methods. Size of the circles is proportional to the number of taxa (represented by BINS) collected by each method. Numbers in overlap areas indicate shared species, numbers in parentheses are total species, and numbers outside parentheses indicate species exclusive per each sampling gear. 
precise picture of all species dwelling in this kind of systems.

Finally, we consider this as the first step for a future biomonitoring program, in which technologies such as environmental DNA and high-throughput sequencing (Cristescu, 2014) will be able to detect any change of the zooplankton community. These changes could be a result of the introduction of invasive species, pollution or tourist development that has been fast in this region during the last two years.

\section{ACKNOWLEDGMENTS}

The results presented here are part of a graduate thesis of the first author, being conducted in El Colegio de la Frontera Sur, with funds of the National Council of Science and Technology (CONACYT) scholarship and the project CONACYT-280896 granted to the Mexican Barcode of Life (MEXBOL) network. We thank Jose Angel Cohúo Colli, Alexei Elías Valdez and Iurthitsi Elías Valdez for the field assistance. Alma Estrella García Morales from the Chetumal Node of MEXBOL assisted with molecular analyses. Lourdes Vasquez Yeomans and Martha Gutierrez Aguirre provided constructive criticism of this work. We acknowledge support and facilities given by the personnel from the Restaurant "Cenote Azul," especially Mr. Javier Romero Soto.

\section{REFERENCES}

Attayde JL, Hansson LA, 2001. The relative importance of fish predation and excretion effects on planktonic communities. Limnol. Oceanogr. 46:1001-1012.

Barr D, 1979. Water mites (Acari:Parasitengona) sampled with chemoluminescent bait in underwater traps. Int. J. Acarol. 5:187-194.

Cervantes-Martínez A, Gutiérrez-Aguirre MA, 2015. Physicochemistry and zooplankton of two karstic sinkholes in the Yucatan Peninsula, Mexico. J. Limnol. 74:382-393. doi: 10.4081/jlimnol.2014.976

Cervantes-Martínez A, Mezeta-Barrera M, Gutiérrez-Aguirre M, 2009. [Limnología básica del lago cárstico turístico Cenote Azul en Quintana Roo, México].[Article in Spanish]. Hidrobiologica 19:177-180.

Colwell RK, 2013. EstimateS: Statistical estimation of species richness and shared species from samples. Version 9. User's Guide and application published at: http://purl.oclc.org/ estimates.

Cook DR, 1980. Studies on neotropical water mites. Mem. Am. Entomol. Inst. 31:1-695.

Cristescu ME, 2014. From barcoding single individuals to metabarcoding biological communities: towards an integrative approach to the study of global biodiversity. Trends. Ecol. Evol. 29:566-571.

Davies B, 1976. A trap for capturing planktonic chironomid larvae. Freshwater Biol. 6:373-380.
Deevey ES, Brenner M, Binford MW, 1980. Structure of zooplankton communities in Peten Lake distric, Guatemala, p. 669-678. In C. Kerfoot (ed.), Evolution and ecology of zooplankton communities. University Press of New England, Lebanon.

DeLorenzo ME, Taylor LA, Lund SA, Pennington PL, Stroizer ED, Fulton MH, 2002. Toxicity and bioconcentration potential of the agricultural pesticide endosulfan in phytoplankton and zooplankton. Arch. Environ. Contam. Toxicol. 42:173-181.

Devries DR, Stein RA, 1991. Comparison of 3 zooplankton samplers - a taxon-specific assessment. J. Plankton Res. 13:53-59.

Dodson S, 1990. Predicting diel vertical migration of zooplankton. Limnol. Oceanogr. 35:1995-1200.

Dumont HJ, Tundisi JG, 1984. Preface. Hydrobiologia 113: VIIVIII. doi: https://doi.org/10.1007/BF00026589

Elías-Gutiérrez M, Smirnov NN, Suárez-Morales E, DimasFlores N, 2001. New and little known cladocerans (Crustacea: Anomopoda) from the southeastern Mexico. Hydrobiologia 442:41-54.

Elías-Gutiérrez M, Cervantes-Martínez A, Gutiérrez-Aguirre MA, Arce-Ibarra AM, 2007. [Los Cenotes y lagunas del centro y sur de la península de Yucatán], p. 423-446. In G. de Lanza-Espino (ed.), [Las aguas interiores de México: conceptos y casos].[Book in Spanish]. AGT Editor, México.

Elías-Gutiérrez M, Martínez-Jerónimo F, Ivanova NV, ValdezMoreno M, 2008a. DNA barcodes for Cladocera and Copepoda from Mexico and Guatemala, highlights and new discoveries. Zootaxa 1849:1-42.

Elías-Gutiérrez M, Suárez-Morales E, Gutiérrez-Aguirre M, Silva-Briano M, Granado-Ramírez J, Garfias-Espejo T, 2008b. [Cladócera y Copépoda de las aguas continentales. Guía Ilustrada].[Book in Spanish]. CONABIO, UNAM, México: 322 pp.

Elías-Gutiérrez M, Valdez-Moreno M, Topan, J, Young MR, Cohuo-Colli JA, 2018. Improved protocols to accelerate the assembly of DNA barcode reference libraries for freshwater zooplankton. Ecol. Evol. 8:3002-3018.

Florian N, Lopez-Luque R, Ospina-Alvarez N, Hufnagel L, Green AJ, 2016. Influence of a carp invasion on the zooplankton community in Laguna Medina, a Mediterranean shallow lake. Limnetica 35:397-411.

García-Morales E, Elías-Gutiérrez M, 2004. Rotifera from southeastern Mexico, new records and comments on zoogeography. Anales del Instituto de Biología UNAM 75:99-120.

Goldschmidt T, 2016. Water mites (Acari: Hydrachnidia): powerful but widely neglected bioindicators - a review. Neotrop. Biodivers. 2:2-25.

González-Sánchez VH, Johnson JD, Garcia-Padilla E, MataSilva V, DeSantis DL, Wilson DL, 2017. The herpetofauna of the Mexican Yucatan Peninsula: composition, distribution and conservation status. Mesoamerican Herpetology 4:264-380.

Hajibabaei M, DeWaard JR, Ivanova NV, Ratnasingham S, Dooh R, Kirk SL, Mackie PM, Hebert PDN, 2005. Critical factors for assembling a high volume of DNA barcodes. Philos.T. Roy. Soc. B. 360:1959-1967.

Hajibabaei M, Spall JL, Shokralla S, Konynenburg SV, 2012. 
Assessing biodiversity of a freshwater benthic macroinvertebrade community through non-destructive environmental barcoding of DNA from preservative ethanol. BMC Ecol.12:28.

Harris R, Wiebe P, Lenz J, Skjoldal HR, Huntley M, 2000. ICES Zooplankton Methodology Manual. Academic Press, London: 684 pp.

Hebert PD, Cywinska A, Ball SL, deWard JR, 2003. Biological identifications through DNA barcodes. Proc. Biol. Sci. 270:313-21.

Holynska M, Reid J, Ueda H, 2003. Guides to the identification of the microinvertebrates of the continental waters of the world. Copepoda: Cyclopoida genera Mesocyclops and Thermocyclops. Backhuys, Amsterdam: 318 pp.

Hungerford HB, Spangler PJ, Walker NA, 1955. Subaquatic light traps for insects and other animal organisms. Trans. Kans. Acad. Sci. 58:387-407.

Ivanova NV, DeWaard JR, Hebert PDN, 2006. An inexpensive, automation-friendly protocol for recovering high-quality DNA. Mol. Ecol. Notes 6:998-1002.

Janz P, Weltje L, Ebke KP, Dawo U, 2016. Temporal population dynamics of the phantom midge Chaoborus crystallinus and its influence on the zooplankton community. Hydrobiologia 770:273-287.

Jeppesen E, Leavitt P, De Meester L, Jensen JP, 2001. Functional ecology and palaeolimnology: using cladocerans remains to reconstruct anthropogenic impact. Trends Ecol. Evol. 16:191-198.

Keller W, Gunn JM, Yan ND, 1992. Evidence of biological recovery in acid-stressed lakes near Sudbury, Canada. Environ. Pollut. 78:79-85.

Kimura M, 1980. A simple method of estimating evolutionary rate of base substitutions through comparative studies. J. Mol. Evol. 16:111-120.

Koste W, 1978. [Rotatoria. Die Rädertiere Mitteleuropas. Ein Bestimmungswerk, begründet von Max Voigt. Überordnung Monogonta I Textband].[Book in German]. Gebrüder Borntraeger, Berlin: 673 pp.

Kotov AA, Garfias-Espejo T, Elías-Gutiérrez M, 2004. Separation of two Neotropical species: Macrothrix superaculeata (Smirnov, 1982) versus M. elegans Sars 1901 (Macrothricidae, Anomopoda, Cladocera). Hydrobiologia 517:61-88.

Kumar S, Stecher G, Tamura K, 2016. MEGA7: Molecular evolutionary genetics analysis version 7.0 for bigger datasets. Mol. Biol. Evol. 33:1870-1874.

Larigauderie A, Prieur-Richard AH, Mace GM, Lonsdale M, Mooney HA, Brussaard L, Cooper D, Cramer W, Daszak P, Díaz S, Duraiappah A, Elmqvist T, Faith DP, Jackson LE, Krug C, Leadley PW, Le Prestre P, Hiroyuki M, Palmer M, Perrings C, Pulleman M, Reyes B, Rosa EA, Scholes RJ, Spehn E, Turner BL, Yahara T, 2012. Biodiversity and ecosystem services science for a sustainable planet: the DIVERSITAS vision for 2012-20. Curr. Opin. Environ. Sust. 4:101-105.

Lindegaard C, 1995. Classification of water-bodies and pollution, p. 385-404. In: P.D. Armitage, L.C. Pinder and P. Cranston (eds.), The Chironomidae: The biology and ecology of non-biting midges. Chapman \& Hall, London.

Loera-Barocio JC, Lagunes-Tejeda A, Concepción RM, JohansenNaime R, Romero-Nápoles J, Manuel-Pinto V, Aguayo-Silva
G, 2011. [Susceptibilidad a insecticidas en tres poblaciones mexicanas del trips del laurel, Gynaikothrips ficorum (Marchal) (Thysanoptera: Phlaeothripidae)].[Article in Spanish]. Agrociencia 45:61-73.

Marelli DC, Berrend RE, 1978. New species record for Mytilopsis sallei (Recluz) in Central-America (Mollusca Pelecypoda). Veliger 21:144.

Mangas-Ramírez E, Elías-Gutiérrez M, 2004. Effect of mechanical removal of water hyacinth (Eichhornia crassipes) on the water quality and biological communities in a Mexican reservoir. Aquat. Ecosyst. Health Manag. 7:161-168.

Marrero HJ, Zalba SM, Carpintero DL, 2008. [Eficiencia relativa de distintas técnicas de captura de heterópteros terrestres en un pastizal de montaña].[Article in Spanish]. BioScriba 1:3-9.

Martínez-Luque E, Zurita-García M, Zaldívar-Riverón A, 2016. [Inventario de las especies de elatéridos (Coleoptera: Elateridae) de un bosque tropical caducifolio mexicano]. [Article in Spanish]. Rev. Mex. Biodivers. 87:956-965.

Miller RR, Minckley WL, Norris SM, 2009. [Peces dulceacuícolas de México].[Book in Spanish]. CONABIO, México: 545 pp.

Modlin R, Gannon J, 1973. Contribution to the ecology and distribution of aquatic acari in the St. Lawrence Great Lakes. Trans. Am. Microsc. Soc. 92:217-224.

Mutanen M, Kivelä SM, Vos RA, Doorenweerd C, Ratnasingham S, Hausmann A, Huemer P, Dincă V, van Nieukerken EJ, Lopez-Vaamonde C, Vila R, Aarvik L, Decaëns T, Efetov KA, Hebert PDN, Johnsen A, Karsholt O, Pentinsaari M, Rougerie R, Segerer A, Tarmann G, Zahiri R, Godfray HC, 2016. Species-level para- and polyphyly in DNA barcode gene trees: Strong operational bias in European Lepidoptera. Syst. Biol. 65:1024-1040.

Nyman M, Korhola A, Brooks SJ, 2005. The distribution and diversity of Chironomidae (Insecta: Diptera) in western Finnish Lapland, with special emphasis on shallow lakes. Global Ecol. Biogeogr. 14:137-153.

Otero-Colina G, 1987. [Nuevas especies de ácaros acuáticos (Prostigmata: Parasitengona) del Sureste Mexicano].[Article in Spanish]. Folia Entomol. Mex. 72:89-109.

Perry E, Velazquez-Oliman G, Marin L, 2002. The hydrogeochemistry of the karst aquifer system of the northern Yucatan Peninsula, Mexico. Int. Geol. Rev. 44:191-221.

Pfenninger M, Nowak C, Hley C, Steinke D, Streit B, 2007. Utility of DNA taxonomy and barcoding for the inference of larval community structure in morphologically cryptic Chironomus (Diptera) species. Mol. Ecol. 16:1957-1968.

Piu GS, Ceccio MG, Garau S, Palomba AM, Pautasso M, Pittau F, Ballero M, 1992. Itchy dermatitis from Gynaikothrips ficorum March in a family group. Allergy 47:441-442.

Prosser S, Martínez-Arce A, Elías-Gutiérrez M, 2013. A new set of primers for COI amplification from freshwater microcrustaceans. Mol. Ecol. Resour. 13:1151-1155.

Randolph RP, McCafferty WP, 2000. Mexican mayflies: inventory and additions (Ephemeroptera). Annls. Limnol. 36:113-121.

Ratnasingham S, Hebert PDN, 2007. BOLD: The Barcode of Life Data System (www.barcodinglife.org). Mol. Ecol. Notes 7:355-364.

Ratnasingham S, Hebert PDN, 2013. A DNA-based registry for 
all animal species: The Barcode Index Number (BIN) System. PloS One 8:e66213.

Rocha-Ramírez A, Álvarez F, Alcocer J, Chávez-López R, Escobar-Briones E, 2009. [Lista anotada de los isópodos acuáticos epicontinentales de México (Crustacea: Isopoda)].[Article in Spanish]. Rev. Mex. Biodivers. 80:615-631.

Shiel RJ, Walker KF, Williams WD, 1982. Plankton of the lower River Murray, South Australia. Aust. J. Mar. Freshw. Res. 33:301-327.

Smirnov NN, Elías-Gutiérrez M, 2011. Biocenotic characteristics of some Yucatan lentic water bodies based on invertebrate remains in sediments. Inland Water Biol. 4:211-217.

Suárez-Morales E, Reid JR, Iliffe T, Fiers F, 1996. Catálogo de copépodos (Crustacea) continentales de la Península de Yucatán, México. CONABIO/ECOSUR México: 296 pp.

Teletchea F, 2010. After 7 years and 1000 citations: Comparative assessment of the DNA barcoding and the DNA taxonomy proposals for taxonomists and non-taxonomists. Mitochondr. DNA 21:206-226.

Vásquez-Yeomans L, Vega-Cendejas ME, Montero JL, SosaCordero E, 2011. High species richness of early stages of fish in a locality of Mesoamerican Barrier Reef System: a small-scale survey using different sampling gears. Biodivers. Conserv. 20:2379-2392.

Vinogradova EM, Riss HW, 2007. Chironomids of Yucatan Peninsula. Chironomus 20:32-35.

Walseng B, Karlsen LR, 2001. Planktonic and littoral microcrustaceans as indices of recovery in limed lakes in SE Norway. Water Air Soil. Pollut. 130:1313-1318.

\section{Data accessibility}

BOLD Dataset: DS CAZUL 01 